\title{
Pharmacokinetics and Pharmacodynamics of Hyaluronan Infused into Healthy Human Volunteers
}

\author{
Sara Rae Hamilton ${ }^{\#, 1}$, Mandana Veiseh ${ }^{\#, 2}$, Cornelia Tölg${ }^{\#, 3}$, Rommel Tirona ${ }^{4}$, Jakob Richardson ${ }^{3}$, \\ Richard Brown ${ }^{5}$, Mario Gonzalez ${ }^{6}$, Michael Vanzieleghem ${ }^{7}$, Patricia Anderson ${ }^{8}$, Samuel Asculai ${ }^{9}$, \\ Françoise Winnik $^{10}$, Rashmin Savani ${ }^{11}$, David Freeman ${ }^{12}$, Leonard Luyt ${ }^{13}$, James Koropatnick*, ${ }^{*}$ \\ and Eva Ann Turley*,15
}

\begin{abstract}
${ }^{1}$ London Regional Cancer Program, Cancer Research Laboratories, London, Ontario, Canada, and Department of Biochemistry, University of Western Ontario, London, Ontario, Canada; ${ }^{2}$ Life Sciences Division, Lawrence Berkeley National Laboratories, Berkeley CA; ${ }^{3}$ London Regional Cancer Program, Cancer Research Laboratories, London, Ontario, Canada; ${ }^{4}$ Department of Physiology \& Pharmacology and Division of Clinical Pharmacology, Department of Medicine, Schulich School of Medicine and Dentistry, University of Western Ontario, London, Ontario, Canada; ${ }^{5}$ BioMS Medical Corporation, Edmonton, Alberta, Canada; ${ }^{6}$ P-kinetics Corp., Miami, Florida, USA; ${ }^{7}$ MV Pharmaceutical Consultants, Mississauga, Ontario, Canada; ${ }^{8}$ CanReg Inc., Dundas, Ontario, Canada; ${ }^{9}$ Bio-Strategies Consulting Group, Toronto, Ontario, Canada; ${ }^{10}$ Département de Chimie et Faculté de Pharmacie, Université de Montréal, Pavillon J.A. Bombardier, CP 6128 Succursale Centre Ville, Montréal, QC, Canada; ${ }^{11}$ William Buchanan Chair in Pediatrics, Director, Division of Neonatal-Perinatal Medicine, Associate Director, Division of Pulmonary \& Vascular Biology University of Texas Southwestern Medical Center, Dallas, TX; ${ }^{12}$ Faculty of Medicine, University of Western Ontario, London, Ontario, Canada, ${ }^{13}$ London Regional Cancer Program, Cancer Research Laboratories and Department of Chemistry; ${ }^{14}$ London Regional Cancer Program, Cancer Research Laboratories and Departments of Oncology, Microbiology and Immunology, Pathology, and Physiology and Pharmacology, University of Western Ontario and Lawson Health Research Institute, London Health Sciences Centre, London, Ontario, Canada; ${ }^{15}$ London Regional Cancer Program, Cancer Research Laboratories (London, Ontario, Canada) and Departments of Biochemistry and Oncology, University of Western Ontario, London, Ontario, Canada
\end{abstract}

\begin{abstract}
The pharmacodynamics and elimination kinetics of escalating doses (1.5-12 $\mathrm{mg} / \mathrm{kg})$ of hyaluronan (HA) infusions were studied in healthy human volunteers. Metabolic breakdown of serum HA and associated adverse events were monitored throughout the study. The HA-binding capacities of circulating CD4+ and CD8+ T lymphocytes, CD19+ Blymphocytes and CD14+ peripheral blood monocytes (PBMC) were also quantified. Breakdown of infused HA into small fragments $(<37 \mathrm{kDa})$ were not detected and adverse events related to HA infusions were infrequent and non-serious in nature. Binding of FITC-HA was greatest to CD14+ monocytes and the binding capacity of these cells for FITC-HA was significantly increased by the final HA infusion. At that time, binding to CD14+ monocytes was related to serum HA levels suggesting a close relationship between PK and PD of serum HA. Drug level analysis demonstrated a disproportional increase in the area under the serum concentration vs. time curve with increasing HA dose. The observed non-linear HA kinetics appears to result from a saturable elimination process as revealed by pharmacokinetic modeling. These results have implications for the use of injected HA for drug delivery or in imaging applications.
\end{abstract}

\section{INTRODUCTION}

HA is an ubiquitous glycosaminoglycan produced by three distinct but homologous HA synthases (HAS1-3) and is degraded by five known hyaluronidases (HYAL1-5) most of which are lysosomal. HA is retained in tissues as a result of specific interactions with extracellular and cellular HAbinding proteins defined as hyaladherins and amounts are regulated during morphogenesis, wound repair, chronic inflammatory disorders, and neoplasia [1,2]. Altered tissue HA results from changes in the activity and expression of

\footnotetext{
*Address correspondence to these authors at the London Regional Cancer Program, 790 Commissioners Rd E, London, Ontario, N6A4L6. Business, Canada; Tel: 519-685-8600 ext 53677; Fax: 519-685-6816; E-mail: eva.turley@lhsc.on.ca; jkoropat@uwo.ca

"These authors contributed equally.
}

HAS and hyaluronidases as well as rate of HA uptake into the cell [3-6]. HA modifies the physico-chemical nature of the extracellular matrix within tissues and contributes to both homeostasis and response-to-injury processes [1, 4, 5, 7-10]. For example, interactions with cell receptors activates signaling cascades that promote migration and proliferation, which consequently influence both differentiation and immune trafficking/function during tissue homeostasis and response-toinjury $[2,11]$. HA is metabolized in multiple compartments including tissues, lymphatics and vasculature [6] and alteration of this metabolism can have serious consequences to homeostasis. For example, modification of tissue HA metabolism during response-to-injury promotes unremitting, non-resolving inflammation $[4,12]$. A proportion of tissue HA escapes into the lymphatics, is processed in lymph nodes and from there gains entry into the blood vasculature [13]. 
Uptake and metabolism of HA occurs in each of these compartments as well. Endocytosis of HA by liver, and to a lesser extent kidney endothelium, removes most serum HA [14]. Ultimately HA is degraded in lysosomes by hyaluronidases [15, 16].

In spite of this limited knowledge of both the metabolic fate and functions of HA, it is currently extensively used in humans (e.g. for joint supplementation and tissue replacement, surgical adhesion prevention, regulation of inflammatory diseases, tissue healing/regeneration and tissue engineering) [17-20]. Future products of HA or modified HA are also being developed to enhance targeted drug delivery into traditionally inaccessible compartments such as tumors, peripheral lymph nodes, and bone marrow [21-23]. HA is also being investigated as an imaging agent. For example, increased HA accumulation at the periphery of invading breast tumors enhances ultrasound detection of the margins of the invading tumor [24]. HA can be readily modified with nonspecific contrast agents such as metals, and these complexes are being studied for their ability to detect areas of altered HA metabolism [25].

The current clinical uses of HA often result in repeated exposure of patients to high levels of exogenous HA in se- rum, far exceeding normal serum concentrations, which are in the order of ug/L [26]. Surprisingly few studies have addressed the pharmacokinetics or dynamics of the exogenous HA polymer itself or in combination with other drugs [27, 28 ] and to our knowledge there are no reports of the pharmacodynamics of chronically administered, high dose $(\mathrm{mg} / \mathrm{kg})$ exogenous HA under conditions that patients might experience when HA is used as a delivery vehicle for therapeutic reagents. Since quantifying the pharmacokinetics of administered HA is an essential first step to characterize its pharmacodynamics for identifying potential deleterious side effects of exogenous HA, and for further refinement of HA as a drug delivery and imaging agent, we assessed the elimination kinetics and toxicity of multiple, escalating doses of HA from $1.5 \mathrm{mg} / \mathrm{kg}-12 \mathrm{mg} / \mathrm{kg}$ administered to healthy male and female human volunteers over a 4 week period.

\section{SUBJECTS, MATERIALS AND METHODS}

\section{Patient Eligibility}

Twelve non-smoking male and 12 non-smoking female volunteers, 30-50 years of age, weighing at least $60 \mathrm{~kg}$ (males) or $45 \mathrm{~kg}$ (females), and who were within $15 \%$ of their optimum weight [29] were enrolled in this study by

Table 1. Patient Demographics and Exclusion Criteria

\begin{tabular}{|c|c|}
\hline A. Patient Demographics & $\begin{array}{l}12 \text { males, } 12 \text { females } \\
{ }^{a} \text { Non-Smokers } \\
\text { Age ( } 30-50 \mathrm{yrs} \text { ) } \\
{ }^{\mathrm{b}} \text { Weight (avg. } 60 \mathrm{~kg} \text { for males, } 45 \mathrm{~kg} \text { for females) } \\
\text { Height (avg. } 178 \mathrm{~cm} \text { for males, } 160 \mathrm{~cm} \text { for females) }\end{array}$ \\
\hline $\begin{array}{l}\text { B. Medical Histories } \\
\text { (for exclusion from study) }\end{array}$ & $\begin{array}{l}\text { Significant Cardiovascular disease } \\
\text { Significant hepatic disease } \\
\text { Significant renal disease } \\
\text { Significant CNS disease } \\
\text { Significant hematological disease } \\
\text { Significant gastrointestinal disease } \\
\text { Clinically significant illness } 4 \text { weeks prior to study entry } \\
\text { Alcoholism or drug abuse in previous year before study entry } \\
\text { Hypersensitivity or idiosyncratic reaction to HA or other GAG } \\
\text { Pregnancy } \\
\text { Nursing } \\
\text { Inadequate contraception } \\
\text { 'Personality disorders } \\
\text { Conditions interfering with drug absorption, distribution, metabolism or excretion } \\
\text { Use of enzyme inducing drugs within } 30 \text { days of study entry } \\
\text { Treatment drugs toxic to major organs within } 3 \text { months of study entry } \\
\text { Abnormal diet during } 4 \text { weeks preceding study } \\
\text { Through completion of study, donation of }>900 \text { mL of blood over } 20 \text { weeks } \\
\text { Participation a drug study } 4 \text { weeks prior to study entry }\end{array}$ \\
\hline C. Prohibited (for duration of study) & $\begin{array}{l}{ }^{\mathrm{d}} \text { Medication (including over-the-counter products) } \\
\text { Use of alcohol-containing or xanthine-containing beverages through sample collection }\end{array}$ \\
\hline
\end{tabular}

See Methods and Results sections for descriptions of procedures.

${ }^{a}$ Subjects could not have used nicotine within 3 months of study entry.

bPatients were within 15\% of their ideal weight ("Table of Desirable Weights of Adults", Metropolitan Life Insurance Company, 1983).

'Includes disorders that would preclude informed consent or compliance with protocol requirements.

${ }^{\mathrm{d}}$ If medication other than that specified in the protocol was required, decision to continue subject was made by L.A.B. Medical Personnel. 
L.A.B. Pharmacological Research International Clinical Research Center (Montreal, Canada). Subjects were further screened for medical histories/demographic data (Table 1). All underwent a complete physical examination and standard laboratory tests to detect medical abnormalities (Table 2). Participants were restricted to non-smoking, medically healthy subjects with clinically acceptable laboratory profiles. Exclusion criteria are listed in Table $\mathbf{1}$.

\section{Ethical Approval}

The protocol was reviewed and approved (IND\#BV520002) by TPD (formerly HPB, Regulatory Body of Canada). The protocol was also internally reviewed by the L.A.B.
Pharmacological International Institution Review Board and was carried out in accordance with established clinical research guidelines [30,31]; and the principles enunciated in the Declaration of Helsinki [32]. The purpose of the study, the procedures that were carried out, and the potential hazards were described to the subjects in non-technical terms in conformity with regulatory requirements.

\section{Study Design}

This was a single-dose, dose escalation, pharmacokinetic study. The primary objective was to evaluate the pharmacokinetic profile of HA after 120 min intravenous infusion of a sterile $1 \%$ HA solution at escalating doses of $1.5 \mathrm{mg} / \mathrm{kg}$,

\section{Table 2. Clinical Laboratory Tests Performed on Subjects}

\begin{tabular}{|c|c|}
\hline A. Hematology $y^{a}$ & $\begin{array}{l}\text { hemoglobin }^{\mathrm{d}} \\
\text { hematocrit }^{\mathrm{d}} \\
\text { total and differential leukocyte count } \\
\text { red blood cell count } \\
\text { platelet count } \\
\text { calculated indices } \\
\text { sedimentation rate } \\
\text { PT/PTT }\end{array}$ \\
\hline B. Serum Chemistry ${ }^{a}$ & $\begin{array}{l}\text { BUN } \\
\text { creatine } \\
\text { total bilirubin } \\
\text { alkaline phosphatase }^{\mathrm{e}} \\
\text { SGOT }^{\mathrm{e}} \\
\mathrm{SGPT}^{\mathrm{e}} \\
\mathrm{LDH} \\
\text { sodium } \\
\text { potassium } \\
\text { calcium } \\
\text { phosphorus } \\
\text { glucose } \\
\text { B-HCG (for female subjects only) }\end{array}$ \\
\hline C. Urinalysis ${ }^{\mathrm{a}}$ & $\begin{array}{l}\mathrm{pH} \\
\text { specific gravity } \\
\text { protein } \\
\text { glucose } \\
\text { ketones } \\
\text { bilirubin } \\
\text { blood } \\
\text { nitrate } \\
\text { urobilinogen-microscopic examination } \\
\text { B-HCG (for female subjects only) }\end{array}$ \\
\hline D. Urine drugs-of-abuse screen ${ }^{c}$ & $\begin{array}{l}\text { cocaine } \\
\text { cannabis }\end{array}$ \\
\hline E. Other ${ }^{c}$ & HIV \\
\hline
\end{tabular}

See Methods and Results sections for descriptions of procedures.

${ }^{\mathrm{a}}$ Conducted at screening and post study.

${ }^{\mathrm{b}}$ Conducted prior to entry into each section.

${ }^{\mathrm{c}}$ Conducted at screening only.

${ }^{\mathrm{d}}$ Conducted prior to and following period 4 .

${ }^{\mathrm{e}}$ Conducted at $72 \mathrm{hrs}$. post-dose in periods 1,2 , and 3 . 
$3.0 \mathrm{mg} / \mathrm{kg}, 6.0 \mathrm{mg} / \mathrm{kg}$ and $12 \mathrm{mg} / \mathrm{kg}$. Each dose subsequent to the $1.5 \mathrm{mg} / \mathrm{kg}$ dose was administered following a 7-day washout period. In each case a total volume of $250 \mathrm{ml}$ of stock solution of HA, diluted appropriately with $0.9 \%$ sodium chloride, was administered over a period of $120 \mathrm{~min}$. Blood was sampled from all volunteers at $2,1.5,1$, and $0.5 \mathrm{~h}$ before administration and at 2, 4, 6, 10, 14, 18, 22, 32, 38, 50 and $74 \mathrm{~h}$ after administration of the HA solution. Blood samples were collected and serum HA levels were measured on site by L.A.B., Inc.. Blood collected from a subset of six subjects ( 3 females and 3 males) at $0,1,4,12,24$ and $72 \mathrm{~h}$ post-infusion of each HA dose were analyzed to determine the molecular weight profile of serum HA and to assess HA binding by $\mathrm{T}$ cells, B cells and blood monocytes. Measurement of these parameters was the first step in assessing pharmacodynamic disposition of HA and as described below. Samples were not segregated according to gender.

\section{Antibodies and Reagents}

FMC63 (CD19) antibody was conjugated to PE. PE conjugated CD4 and CD8 antibodies were purchased from Becton Dickinson (San Jose, CA). Isotype matched control monoclonal antibodies (mAb) were from Southern Biotech (Birmingham, AL). For infusions, lyophilized HA (medical grade, lyophilized HA form prepared by Hyal Pharma, Mississauga ON from original fermented HA product purchased from Kyowa Hakkos, Japan) was dissolved in phosphate buffered saline (PBS) and autoclaved to sterilize and reduce molecular weight. HA samples from this commercial source were analyzed with respect to MW using HPLC/SEC multiangle laser light scattering (LifeCore Biomedical, MS). For cell binding assays, HA (Healon, medical grade) was obtained from Pharmacia (Dorval ZB) and conjugated to fluorescein (FITC) as described previously [33].

\section{Assessment of HA Purity}

HA preparations were tested for the presence of protein, DNA and endotoxin. Protein content was assayed by absorption at $280 \mathrm{~nm}$. DNA content was determined by electrophoresis of $10-100 \mu \mathrm{g} \mathrm{HA}$ in agarose gels containing $0.7 \%$ agarose and $0.5 \mathrm{mg} / \mathrm{ml}$ ethidium bromide at $100 \mathrm{~V}$ for $3 \mathrm{~h}$. DNA was visualized using a UV transilluminator (wavelength: $302 \mathrm{~nm}$ ) [34]. Endotoxin was detected using a colorimetric Limulus ameobocyte lysate assay with a sensitivity of 0.01 endotoxin units/ml [35].

\section{Injections of $\mathrm{HA}$, Sampling and Pharmacokinetic Assessment}

Each subject received four escalating doses of $1 \%$ HA $(1.5,3.0,6.0$, and $12 \mathrm{mg} / \mathrm{kg})$ one week apart as a $2 \mathrm{~h}$ infusion. Between 8-10 a.m. on day one of the study, blood was drawn from volunteers $2 \mathrm{~h}$ prior to HA infusion, to determine baseline serum HA. Blood was collected in 1 X $1.8 \mathrm{ml}$ citrated vacu-containers (BD Canada, Oakville, On). On the first day, 24 volunteers were infused i.v. with $1.5 \mathrm{mg} / \mathrm{kg} \mathrm{HA}$ (1\%) over a $2 \mathrm{~h}$ period (period 1). Blood was sampled at the times listed above in "Study Design". Subsequently, at 7-day intervals, volunteers were infused with $3.0 \mathrm{mg} / \mathrm{kg}$ (period 2), $6.0 \mathrm{mg} / \mathrm{kg}$ (period 3) and $12 \mathrm{mg} / \mathrm{kg}$ (period 4) and blood samples taken as described for period 1 .

Baseline, endogenous serum HA was 35-40 ng/ml, consistent with that reported in healthy persons $18-65$ years old
[26]. HA serum levels had dropped to these baseline levels in all subjects during the washout period between dose periods. These values were remarkably consistent and were 0.1 $0.4 \%$ of serum $\mathrm{HA}$ at the earliest time point $(0.5 \mathrm{~h})$ after injection of the lowest amount of HA $(1.5 \mathrm{mg} / \mathrm{kg})$. For simplicity of analysis, baseline serum HA levels were subtracted prior to analysis of the data.

Maximum serum concentrations $\left(\mathrm{C}_{\max }\right)$ were the values obtained $2 \mathrm{~h}$ after HA infusion and AUC ("area-undercurve", in a plot of HA concentration $v s$ time infusion [075]) was determined using a linear trapezoid method. Modeldependent analysis of the serum concentration-time profiles was used to estimate zero-order endogenous HA synthesis rate $\left(\mathrm{k}_{\mathrm{syn}}\right)$, saturable elimination process $\left(\mathrm{K}_{\mathrm{m}}\right.$, serum concentration at half-maximal elimination rate; $\mathrm{V}_{\max }$, maximum elimination rate) and one-compartment volume of distribution $\left(\mathrm{V}_{\mathrm{d}}\right)$ (Fig. 1). Hence, the rate of change in HA mass in serum as a function of time was described as:

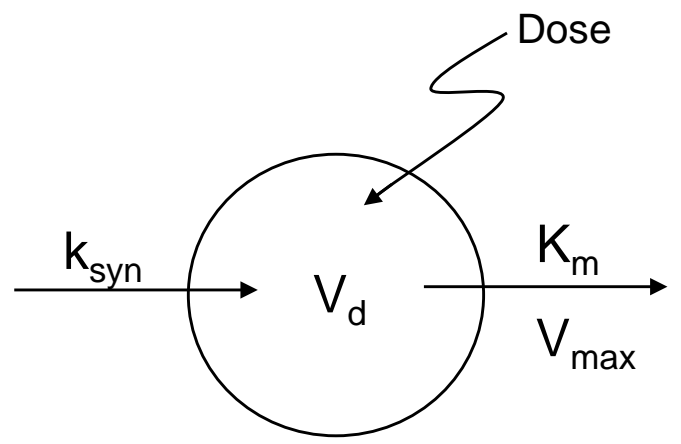

Fig. (1). Hyaluronan Pharmacokinetics Model. The pharmacokinetics of HA was modeled with a one-compartment distribution scheme to which the dose is delivered as a 2-hour infusion. Endogenous HA synthesis is described as a zero-order process $\left(\mathrm{k}_{\mathrm{syn}}\right)$ while the rate of saturable HA elimination is governed by the parameters $K_{m}$ and $V_{\max }$.

$$
\frac{\mathrm{dHA}}{\mathrm{dT}}=\mathrm{k}_{\mathrm{syn}}-\frac{\mathrm{V}_{\max } \mathrm{x}[\mathrm{HA}]}{\mathrm{K}_{\mathrm{m}}+[\mathrm{HA}]}
$$

where the concentration of HA is:

$$
[\mathrm{HA}]=\frac{\mathrm{HA}}{\mathrm{V}_{\mathrm{d}}}
$$

The initial HA concentration was set as the pre-infusion level. It was assumed that the rate of HA appearance in serum $\left(\mathrm{k}_{\mathrm{syn}}\right)$ remained constant over the sampling period. The entire mean data set over time 0 to $75 \mathrm{~h}$ for each dose regimen $(1.5,3,6$, and $12 \mathrm{mg} / \mathrm{kg}$ administered over $2 \mathrm{~h}$ ) was fitted to the model to estimate parameter values using a leastsquares minimization procedure with optimized weighting determined by visual inspection of the fitted result (SCIENTIST, MicroMath Scientific Software, St. Louis, MO). The present model was employed because preliminary kinetic analyses determined that simpler models describing elimination as a single linear function, or more complex models such as those including a combination of saturable and linear clearance processes, did not yield improved fits of the data after comparisons of sums of squared deviation, residual plots, standard deviation of estimates and values for a modified Akaike criterion. 


\section{Clinical Tests Performed to Identify Serious Adverse Reactions}

Clinical laboratory tests (Table 2) were conducted at screening and post-study. $B$-HCG urine levels were assessed in female subjects at screening, prior to entry into each dosing period and post-study (Table 1). Hemoglobin and hematocrit were both tested on screening, prior to entry into the study, prior to and following period 4 dosing, and at the end of the study. Serum alkaline phosphatase, SGOT, and SGPT levels were determined at screening, prior to entry into the study and $72 \mathrm{~h}$ post-dose in periods 1,2 and 3 , and at the end of the study.

\section{Measurement of Serum HA}

The analysis for HA levels in serum samples from 23 healthy volunteers for each time point described above was performed using a Pharmacia HA Test (Kabi Pharma, Upsala, Sweden) based upon the same principles as the presently available HA Test Kit (Echelon). The HA of serum samples reacts with a specific HA binding protein labeled with ${ }^{125} \mathrm{I}$. The limit of quantification (LOQ) of the assay was $10 \mathrm{ng} / \mathrm{ml}$, and the limit of detection (LOD) was $4.73 \mathrm{ng} / \mathrm{ml}$. Inter and intra-day variation of the assay was controlled through incorporation of an analysis of HA analysis standards, provided with the kit.

\section{HA Molecular Weight Analysis}

HA and other glycosaminoglycans were precipitated using cetylpyridinium chloride treatment of serum samples from 6 subjects using the $0.5 \mathrm{hrs}$ and $48 \mathrm{hrs}$ sampling times [35]. Equal amounts of precipitated glycosaminoglycans, detected with a modified anthrone assay, which detects uronic acid, were used for molecular weight analyses [36]. The heterogeneity of HA size range was determined using non-denaturing gel filtration. Precipitates were dissolved in PBS and then passed through a 1.6 x $61.5 \mathrm{~cm}$ Sephacryl 500 column, previously calibrated using dextran standards (MW $11.3-2,000 \mathrm{kDa})$. One $\mathrm{ml}$ fractions from a total $120 \mathrm{ml}$ volume were analyzed for uronic acid. Inter- and intra-day variations in amounts of HA detected with the modified anthrone assay were determined and adjusted for by using HA standards to generate concentration curves for each assay. Elution profile curves were plotted and molecular weight categories of $>2 \times 10^{6}, 1.9 \times 10^{5}-2.0 \times 10^{6}$; and <1.9 × $10^{5}$ were quantified by measuring AUC using Adobe Photoshop to obtain pixel number/unit area.

\section{Measurement of HA Binding by Subsets of Peripheral Blood Mononuclear Cells ( PBMC)}

PBMC were purified by centrifugation over Ficoll PAQUE (Pharmacia, Dorval, QB), washed and stained for surface marker expression as well as for the ability to bind FITC-HA as previously described [33]. To determine the ability of PBMC subsets to bind HA, PBMC were stained in two-color immunofluorescence with PE-coupled mAb to a defined surface marker and HA-FITC. The optimum amount of mAb-PE and of FITC-HA was determined by titration using PBMC from untreated normal donors. HA binding by T cells (CD4+ or CD8+), B cells (CD19+) or monocytes (CD14+) was analyzed in replicate aliquots of each PBMC sample. Isotype-matched $\mathrm{Ab}$ binding was also assessed as a control for background staining.

PBMC stained with mAb-PE and FITC-HA were analyzed by FACS (Becton Dickinson). Data from 10,000 cells (after exclusion of erythrocytes and dead cells) were analyzed using Lysis II software. Cells expressing CD4+, CD8+, CD19+ and CD14+, (depending on the mAb used) were assessed for staining with FITC-HA in each PBMC subset. Auto-fluorescence of PBMC and PBMC stained with IgG-FITC or avidin-FITC were used as negative controls in evaluation of staining by FITC-HA. Staining was moderately bright for FITC-HA for 13 untreated normal donors, with mean fluorescence intensity reported in arbitrary units. HA binding by subsets of PBMC after infusion of HA was compared to the normal values. Assay variability was compensated through assessment of HA binding to CD14+ monocytes (collected at the $20 \mathrm{hr}$ time point from each period) in each FACS analysis.

\section{RESULTS}

\section{Characterization of HA Used for Study}

The average MW of HA used in this study was 276.6 (hereafter referred to as 280) $\mathrm{kDa}$ after heat sterilization (which fragments HA slightly), and $519.7 \mathrm{kDa}$ prior to heat exposure. Protein contamination of less than $0.001 \mu \mathrm{g} / \mathrm{mg}$ was detected (although values obtained were at the lower limit of detection of the assays). DNA contamination in commercial samples of HA, which has the capacity to induce cytokines in monocytes in vitro has been reported [34]. Thus, we assessed samples for DNA contamination but none was detected. Endotoxin was also not detected. These results indicate that contaminants common to commercial HA batches were below the detection limits of our assays.

Table 3. Frequency of Adverse Effects

\begin{tabular}{|l|l|l|l|l|}
\hline Adverse Effects & Frequency & Related to Study & Severity & Subject Continued or Discontinued in Study \\
\hline \hline Influenza & 1 & Unrelated & Mild & Discontinued \\
Lower Arm Rash & 1 & Possibly related & Mild & Continued \\
Headache & 4 & Possibly related & Mild & Continued \\
Pro-thrombin Time & 2 & a'Unrelated & Mild & Continued \\
Practical Thromboplastic Time & 2 & a Unrelated & Mild & Continued \\
Others & 7 & Possibly related & Mild & Continued \\
\hline
\end{tabular}

See Methods and Results sections for descriptions of procedures.

${ }^{\mathrm{a}}$ Levels were altered at normal, endogenous HA levels. 


\section{Toxicity Profile of HA Infusions}

A number of standard toxicity parameters were monitored in this study to aid in identification of any adverse effects (Table 2). A listing of adverse events noted in this study is reported in Table $\mathbf{3}$. One subject left the study due to a minor illness (influenza) unrelated to the treatment. In general HA was well tolerated by all subjects and there were no withdrawals due to study drug effects. Seven subjects experienced 13 mild adverse events. Five of the mild events were possibly related to the study drug (lower arm rash in one subject, and headache in four subjects) while the remaining events were unlikely to be related. At normal endogenous HA levels, both the pro-thrombin time and activated practi- cal thromboplastic time were within their respective reference range for all subjects with the exception of subjects 9 and 18 .

\section{Kinetic Analysis of HA Elimination from Serum}

The study design was based on commonly used standard methods to obtain an optimal dosing regime for bioactive drugs [37]. However, the objective of the study was to evaluate the pharmacokinetic profile of increasing doses of $1 \% \mathrm{HA}$ injected as i.v. infusions over $120 \mathrm{~min}$. Since the doses of i.v. administered HA in the present study were higher than those of previous reports (e.g., [38]) and were escalated over time, each dose was administered by a $2 \mathrm{~h}$

Table 4. Baseline Corrected Hyaluronan Mean Concentration (Cp), ng/mL

\begin{tabular}{|c|c|c|c|c|c|}
\hline & Time (hr) & $\begin{array}{c}1.5 \mathrm{mg} / \mathrm{kg} \text { Mean [+/-SD] } \\
\mathrm{N}=24\end{array}$ & $\begin{array}{c}3.0 \mathrm{mg} / \mathrm{kg} \text { Mean }[+/-\mathrm{SD}] \\
\mathrm{N}=\mathbf{2 4}\end{array}$ & $\begin{array}{c}6.0 \mathrm{mg} / \mathrm{kg} \text { Mean }[+/-\mathrm{SD}] \\
\mathrm{N}=24\end{array}$ & $\begin{array}{c}12.0 \mathrm{mg} / \mathrm{kg} \text { Mean }[+/-\mathrm{SD}] \\
\mathrm{N}=23\end{array}$ \\
\hline \multirow{5}{*}{ 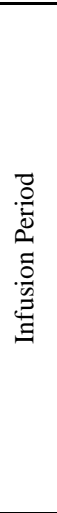 } & $0^{\mathrm{a}}$ & $\begin{array}{c}0 \\
{[0]}\end{array}$ & $\begin{array}{c}0 \\
{[0]}\end{array}$ & $\begin{array}{c}0 \\
{[0]}\end{array}$ & $\begin{array}{c}0 \\
{[0]}\end{array}$ \\
\hline & $0.5^{\mathrm{a}}$ & $\begin{array}{c}7761 \\
{[1130]}\end{array}$ & $\begin{array}{l}17713 \\
{[3021]}\end{array}$ & $\begin{array}{l}38838 \\
{[6162]}\end{array}$ & $\begin{array}{c}77186 \\
{[11297]}\end{array}$ \\
\hline & $1^{\mathrm{a}}$ & $\begin{array}{l}15280 \\
{[2783]}\end{array}$ & $\begin{array}{l}34625 \\
{[5621]}\end{array}$ & $\begin{array}{c}84083 \\
{[13648]}\end{array}$ & $\begin{array}{l}154713 \\
{[26503]}\end{array}$ \\
\hline & $1.5^{\mathrm{a}}$ & $\begin{array}{l}24052 \\
{[3653]}\end{array}$ & $\begin{array}{l}52052 \\
{[9039]}\end{array}$ & $\begin{array}{l}129204 \\
{[16063]}\end{array}$ & $\begin{array}{l}254994 \\
{[40017]}\end{array}$ \\
\hline & $2^{a}$ & $\begin{array}{l}26284 \\
{[3918]}\end{array}$ & $\begin{array}{c}63063 \\
{[16099]}\end{array}$ & $\begin{array}{l}131549 \\
{[17324]}\end{array}$ & $\begin{array}{l}313554 \\
{[41271]}\end{array}$ \\
\hline & 4 & $\begin{array}{l}14419 \\
{[3384]}\end{array}$ & $\begin{array}{l}52167 \\
{[7646]}\end{array}$ & $\begin{array}{l}121122 \\
{[13000]}\end{array}$ & $\begin{array}{l}325913 \\
{[51980]}\end{array}$ \\
\hline & 6 & $\begin{array}{c}4633 \\
{[3518]}\end{array}$ & $\begin{array}{l}36334 \\
{[6390]}\end{array}$ & $\begin{array}{l}104426 \\
{[16384]}\end{array}$ & $\begin{array}{l}264232 \\
{[40440]}\end{array}$ \\
\hline & 10 & $\begin{array}{c}40 \\
{[56]}\end{array}$ & $\begin{array}{l}12934 \\
{[7139]}\end{array}$ & $\begin{array}{c}73627 \\
{[12514]}\end{array}$ & $\begin{array}{c}21550 \\
{[28998]}\end{array}$ \\
\hline & 14 & $\begin{array}{c}24 \\
{[12]}\end{array}$ & $\begin{array}{c}1755 \\
{[3188]}\end{array}$ & $\begin{array}{c}50440 \\
{[13547]}\end{array}$ & $\begin{array}{l}195145 \\
{[32153]}\end{array}$ \\
\hline & 18 & $\begin{array}{c}33 \\
{[19]}\end{array}$ & $\begin{array}{c}61 \\
{[103]}\end{array}$ & $\begin{array}{c}26522 \\
{[13128]}\end{array}$ & $\begin{array}{l}153467 \\
{[22857]}\end{array}$ \\
\hline & 22 & $\begin{array}{l}35 \\
{[7]}\end{array}$ & $\begin{array}{c}23 \\
{[14]}\end{array}$ & $\begin{array}{c}10769 \\
{[12496]}\end{array}$ & $\begin{array}{l}146773 \\
{[27505]}\end{array}$ \\
\hline & 26 & $\begin{array}{c}24 \\
{[16]}\end{array}$ & $\begin{array}{c}19 \\
{[10]}\end{array}$ & $\begin{array}{c}1839 \\
{[4367]}\end{array}$ & $\begin{array}{c}94579 \\
{[31429]}\end{array}$ \\
\hline & 32 & $\begin{array}{c}22 \\
{[17]}\end{array}$ & $\begin{array}{c}7 \\
{[4]}\end{array}$ & $\begin{array}{c}28 \\
{[55]}\end{array}$ & $\begin{array}{c}54615 \\
{[29332]}\end{array}$ \\
\hline & 38 & $\begin{array}{c}18 \\
{[10]}\end{array}$ & $\begin{array}{c}23 \\
{[14]}\end{array}$ & $\begin{array}{c}16 \\
{[11]}\end{array}$ & $\begin{array}{c}21795 \\
{[21939]}\end{array}$ \\
\hline & 50 & $\begin{array}{c}22 \\
{[14]}\end{array}$ & $\begin{array}{c}29 \\
{[10]}\end{array}$ & $\begin{array}{c}16 \\
{[11]}\end{array}$ & $\begin{array}{c}419 \\
{[1373]}\end{array}$ \\
\hline & 74 & $\begin{array}{c}31 \\
{[12]}\end{array}$ & $\begin{array}{c}15 \\
{[10]}\end{array}$ & $\begin{array}{c}22 \\
{[16]}\end{array}$ & $\begin{array}{l}15 \\
{[7]}\end{array}$ \\
\hline
\end{tabular}

${ }^{\mathrm{a}}$ The infusion period was $0-4 \mathrm{hrs}$. 


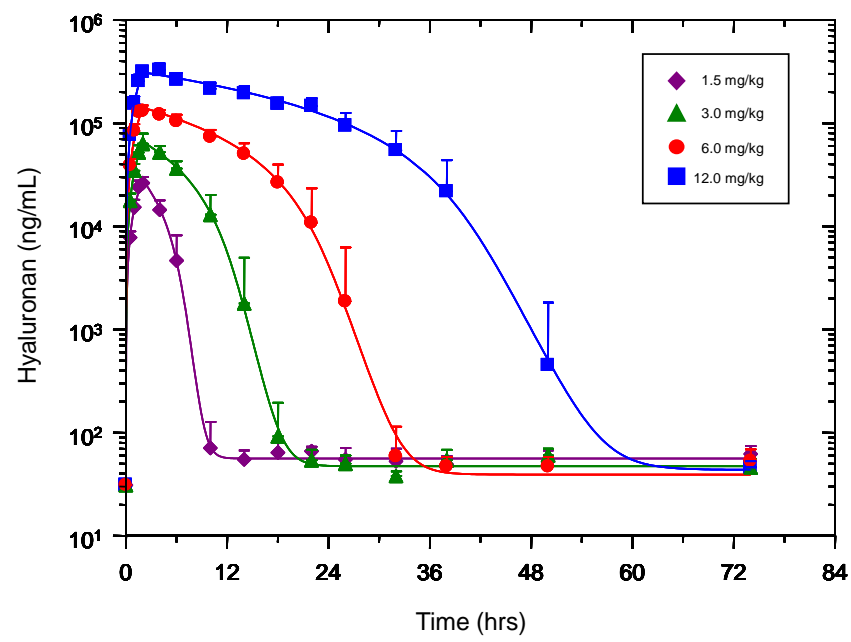

Fig. (2). Hyaluronan serum levels with dose-escalation. HA levels were determined following injection of escalating doses of HA [1.5 mg/kg (period 1), $3 \mathrm{mg} / \mathrm{kg}$ (period 2), $6 \mathrm{mg} / \mathrm{kg}$ (period 3), and $12 \mathrm{mg} / \mathrm{kg}$ (period 4)], administered as an i.v. infusion over $2 \mathrm{~h}$. All values have been corrected for baseline, endogenous serum HA levels. Values represent the mean of $n=24$ for the 1.5, 3.0, and 6.0 $\mathrm{mg} / \mathrm{kg}$ doses and $\mathrm{n}=23$ for the $12 \mathrm{mg} / \mathrm{kg}$ dose. Lines are obtained from least-squares fitting of the mean data for each set to the pharmacokinetic model (Fig. 1).

infusion as this was judged to be safer than the bolus injections used in previous studies. Serum HA concentrations below $40 \mathrm{ng} / \mathrm{ml}$ (baseline levels) were not included for kinetic analyses and were subtracted from all other serum HA values. These corrected levels (Table 4) were plotted against time. The semi-log plot of these data (curve fitted to plotted data points) is shown in Fig. (2). There was a disproportionate increase in HA AUC with increasing dose (Table 5) indicating non-linear pharmacokinetics. By inspection of the log serum concentration $v s$. time profile between $2 \mathrm{~h}$ (end of infusion) and $75 \mathrm{~h}$, the elimination of $\mathrm{HA}$ at all four doses was observed to be consistent with saturable or MichaelisMenten kinetics as evidenced by the concave-down shape (Fig. 2). Indeed, the experimental data fit well with the pharmacokinetic model (Fig. 1) and the exercise yielded parameter values describing the zero-order endogenous formation, one-compartment distribution, and saturable elimination of HA (Table 5). The apparent $V_{d}$ for each dose was not significantly different from one another and the averaged $\mathrm{V}_{\mathrm{d}}$ from all four doses was $38 \mathrm{ml} / \mathrm{kg}$. This value is small but consistent with serum volume. The $\mathrm{V}_{\max }$ for each dose was also very close to one another. The average across the 4 doses was $348 \mathrm{mg} / \mathrm{hr} / \mathrm{kg}$, which is greater than the value reported in an earlier study of a lower dose, bolus injection of HA in human subjects [38]. In contrast to the $V_{d}$ and $V_{\max }$, the $\mathrm{K}_{\mathrm{m}}$ for the first $(1.5 \mathrm{mg} / \mathrm{kg})$ dose is significantly different from the last three doses. The first dose exhibits a smaller $\mathrm{K}_{\mathrm{m}}$ $(6.4 \mathrm{mg} / \mathrm{ml})$ than the other doses (the average of which is $17.6 \mathrm{mg} / \mathrm{ml})$ and the $\mathrm{K}_{\mathrm{m}}$ of the middle two doses $(3.0 \mathrm{mg} / \mathrm{kg}$ and $6.0 \mathrm{mg} / \mathrm{kg})$ is smaller than the largest, final dose (12 $\mathrm{mg} / \mathrm{kg}$ ) (Table 5). The discrepancies amongst these $\mathrm{K}_{\mathrm{m}}$ values may be due to the variability in data sets observed at lower serum HA concentrations and at the extended time periods of sampling (see Fig. 2). However, it is likely that these differences also reflect an altered capacity to eliminate increasing amounts of exogenous HA from serum.

\section{HA Binding to PBMCs}

PBMCs (including $\mathrm{T}$ and $\mathrm{B}$ lymphocytes, and monocytes) have been reported to bind to $\mathrm{HA}$ and to express $\mathrm{HA}$ receptors such as CD44, RHAMM and others [7, 39]. As a first step in assessing pharmacodynamics of exogenous HA infusions, we analyzed these cells that were obtained during each dosing period for their ability to bind FITC-HA (Table 6). All cell types bound FITC-HA above background levels. However, monocytes (CD14+) bound considerably more HA than either B cells (CD19+) or T cells (CD4+ and CD8+). Of the cell types examined, $\mathrm{T}$ cells bound the least amount of FITC-HA, which was close to background levels (Table 6). Total FITC-HA binding to CD14+ PBMC was significantly greater in the $4^{\text {th }}$ dosing period, compared to periods $1-3$ (Fig. 3). Further analysis of the dynamic changes in FITCHA binding over time for each dosing period was conducted by comparing FITC-HA binding levels with HA serum levels. This analysis revealed that FITC-HA binding to circulating monocytes initially increased with rising serum HA levels during all infusion period. Nevertheless, the pharmacodynamics of binding vs. serum levels was different as serum levels began to fall in each dosing period (Fig. 4). In periods 1 and 2, FITC-HA binding to PBMC declined to baseline in rough coordination with return of serum HA levels to baseline. In period 3, FITC-HA binding levels remained above baseline while serum HA levels dropped. Intriguingly, by the $4^{\text {th }}$ period, the rise and fall of serum HA levels were precisely synchronized with the rise and fall of FITC-HA binding to monocytes (Fig. 4). As well, the standard deviations about the means were smallest during the fourth dosing period suggesting a more uniform binding in response of PBMC to increasing HA serum levels than was observed in previous dosing periods. These results suggest that exposure to either a high concentration of HA such as 12

Table 5. Hyaluronan Pharmacokinetics

\begin{tabular}{|c|c|c|c|c|c|c|c|}
\hline Dose & $\begin{array}{c}\mathrm{C}_{\max } \\
(\mathrm{mg} / \mathrm{mL})\end{array}$ & $\begin{array}{c}\mathrm{AUC}_{0-75 \mathrm{~h}} \\
(\mathrm{mg} / \mathrm{hr} / \mathrm{mL})\end{array}$ & $\begin{array}{c}\mathbf{k}_{\mathrm{syn}}{ }^{\mathrm{a}} \\
(\mathrm{mg} / \mathrm{hr} / \mathrm{kg})\end{array}$ & $\begin{array}{c}\mathrm{V}_{\max }{ }^{\mathrm{a}} \\
(\mathrm{mg} / \mathrm{hr} / \mathrm{kg})\end{array}$ & $\begin{array}{c}\mathbf{K}_{\mathrm{m}}{ }^{\mathrm{a}} \\
(\mathrm{mg} / \mathbf{m L})\end{array}$ & $\begin{array}{c}\mathbf{V}_{\max } / \mathbf{K}_{\mathrm{m}} \\
(\mathrm{mL} / \mathrm{hr} / \mathrm{kg})\end{array}$ & $\begin{array}{c}\mathbf{V}_{\mathrm{d}}^{\mathrm{a}} \\
(\mathrm{mL} / \mathrm{kg})\end{array}$ \\
\hline $1.5 \mathrm{mg} / \mathrm{kg}$ & $26 \pm 4$ & 103 & $29 \pm 1.1$ & $340 \pm 34$ & $6.4 \pm 2.1$ & 53.4 & $38.3 \pm 0.9$ \\
\hline $3.0 \mathrm{mg} / \mathrm{kg}$ & $63 \pm 16$ & 407 & $1.3 \pm 0.4$ & $348 \pm 13$ & $11.8 \pm 1.3$ & 29.5 & $38.4 \pm 0.4$ \\
\hline $6.0 \mathrm{mg} / \mathrm{kg}$ & $131 \pm 17$ & 1503 & $0.9 \pm 0.4$ & $334 \pm 16$ & $14.6 \pm 2.7$ & 22.9 & $38.8 \pm 1.4$ \\
\hline $12.0 \mathrm{mg} / \mathrm{kg}$ & $314 \pm 41$ & 5930 & $0.6 \pm 0.4$ & $371 \pm 11$ & $26.5 \pm 3.4$ & 14 & $36.7 \pm 0.8$ \\
\hline
\end{tabular}

See Methods and Results sections for descriptions of calculation of $\mathrm{C}_{\max }$ and plasma concentration of $\mathrm{AUC}_{0-75} \mathrm{~h}$ (area-under-concentration curve from 0 to $75 \mathrm{~h}$ ) and ${ }^{\mathrm{a}} \mathrm{Estimated}$ value \pm S.D. using model-dependent analysis. 
Table 6. Peak HA Binding ${ }^{a}$ by T (CD4+, CD8+) and B (CD19+) Cells in Response to Escalating Doses of HA

\begin{tabular}{|c|c|c|c|c|c|c|c|c|c|c|c|c|}
\hline \multirow[b]{2}{*}{ hours } & \multicolumn{3}{|c|}{ Period 1} & \multicolumn{3}{|c|}{ Period 2} & \multicolumn{3}{|c|}{ Period 3} & \multicolumn{3}{|c|}{ Period 4} \\
\hline & CD4+ & CD8+ & CD19+ & CD4+ & CD8+ & CD19+ & CD4+ & CD8+ & CD19+ & CD4+ & CD8+ & CD19+ \\
\hline 0.5 & 20 & 18 & 50 & 10 & 10 & 80 & 8 & 8 & 30 & 10 & 10 & 10 \\
\hline 2 & 25 & 20 & 70 & 12 & 13 & 95 & 10 & 12 & 100 & 20 & 20 & 50 \\
\hline 14 & 35 & 30 & 90 & 8 & 8 & 50 & 8 & 8 & 90 & 25 & 15 & 60 \\
\hline 26 & 5 & 5 & 75 & 10 & 10 & 60 & 8 & 8 & 80 & 25 & 20 & 35 \\
\hline 74 & 5 & 5 & 40 & 10 & 10 & 40 & 8 & 8 & 80 & 20 & 20 & 40 \\
\hline
\end{tabular}

${ }^{\mathrm{a}} \mathrm{HA}$ binding values have been adjusted for background binding ( $=2$ units).

$\mathrm{mg} / \mathrm{kg}$ or to previous lower doses (e.g., periods 1-3) enhanced the ability of circulating monocytes to modulate HA binding in response to serum HA levels (e.g., cells bind more HA when serum HA levels are high and less when serum levels of HA are low). These results also suggest that HA binding capacity may be affected by exposure to high serum HA levels/previous dosing periods. To estimate binding capacity, a ratio of FITC-HA binding to serum HA levels was calculated for each dosing period (Fig. 5). Binding capacity measured in this manner was similar during HA infusion of all dosing periods and the binding capacity of monocytes did not change during the remainder of the first period. However, between 14-74 hrs of the $2^{\text {nd }}$ period, binding increased and reached a maximum between 14-74 hrs of the $3^{\text {rd }}$ and $4^{\text {th }}$ dosing periods (Fig. 5). It is likely that high serum levels during the infusion period saturated available binding sites and these can be detected only as serum HA levels drop.

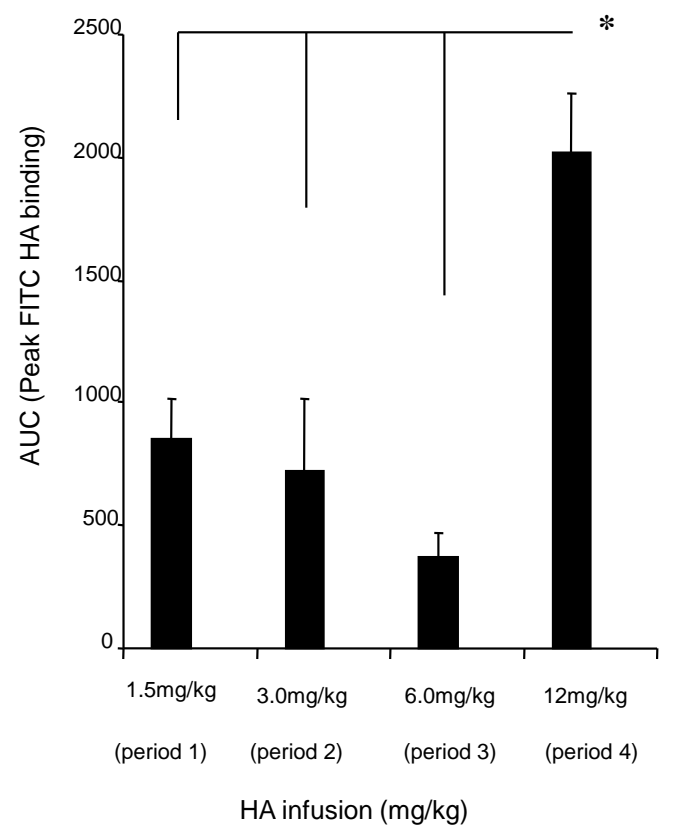

Fig. (3). Total FITC-HA binding to CD14+ PBMC for each dosing period. The binding of FITC-HA to CD14+ PBMC (monocytes) was quantified by FACS and total binding was calculated by measuring AUC as described in Subjects, Materials and Methods. Values represent the mean of samples from 6 volunteers \pm SE. AUC was significantly greater in the $4^{\text {th }}$ dosing period when compared to periods $1-3(\mathrm{P}<0.0001)$.
These results confirm that the binding capacity of circulating monocytes is modified by exposure to the higher serum HA levels achieved in dosing periods 2-4. Although there was also a trend towards enhanced binding of FITC-HA to B cells in the fourth dosing period, this did not reach significance ( $\mathrm{p}=0.10$, data not shown). Significant differences in $\mathrm{HA}$ binding to CD4+ and CD8+ T cells were also not detected (data not shown).

\section{Molecular Weights of Serum HA}

The HA administered to human subjects had an average MW of $280 \mathrm{KDa}$. Molecular weight analyses of serum HA, precipitated from serum using CPC, were quantified as AUC following separation with non-denaturing gel filtration as shown in Fig. (6A). The molecular weight profiles of serum HA from one volunteer are shown (Fig. 6B), $2 \mathrm{~h}$ prior to the last infusion of HA (period 4, $12 \mathrm{mg} / \mathrm{kg}$ ), mid-infusion and $72 \mathrm{~h}$ after infusion. As can be seen from the profile of this volunteer, most of the serum HA chromatographs as a high molecular weight material prior to and after HA injection. Since the exogenous HA used in this study was approximately $280 \mathrm{kDa}$, it is likely that the $>2000 \mathrm{kDa}$ material represents HA complexed with serum proteins [40-42]. The AUC were calculated from the molecular weight profiles of six volunteers as $>2000 \mathrm{kDa}, 185-500 \mathrm{kDa}$ (the size range of the infused $\mathrm{HA}$ ) and $<37 \mathrm{kDa}$ (the size range containing smaller HA fragments, which can be bioactive). The total amount of serum HA, calculated as AUC, did not change over time, which is an expected result since equal amounts of CPC-precipitated serum HA were originally loaded onto the columns. Analysis of these MW fractions over time showed an increase in the $185-500 \mathrm{kDa}$ fraction with infusion of exogenous HA, and likely represents the the $280 \mathrm{kDa}$ exogenous HA since this would partition in this MW range. Interestingly, while the high molecular weight HA complexes did not change over time the smallest HA MW fraction $(<37.7 \mathrm{kDa})$ significantly decreased after exogenous HA infusion (Fig. 6C, p $<0.01$ ).

\section{DISCUSSION}

HA is one of the most clinically utilized of polysaccharides [43, 44]. It is approved for topical applications [45, 46], for internal visco-supplementation (e.g., as an injected treatment for osteoarthritis in knee joints $[44,47])$, for preventing tissue damage during and following eye surgery $[48,49]$ and as a post-surgical adhesion preventative [50]. More recently, 

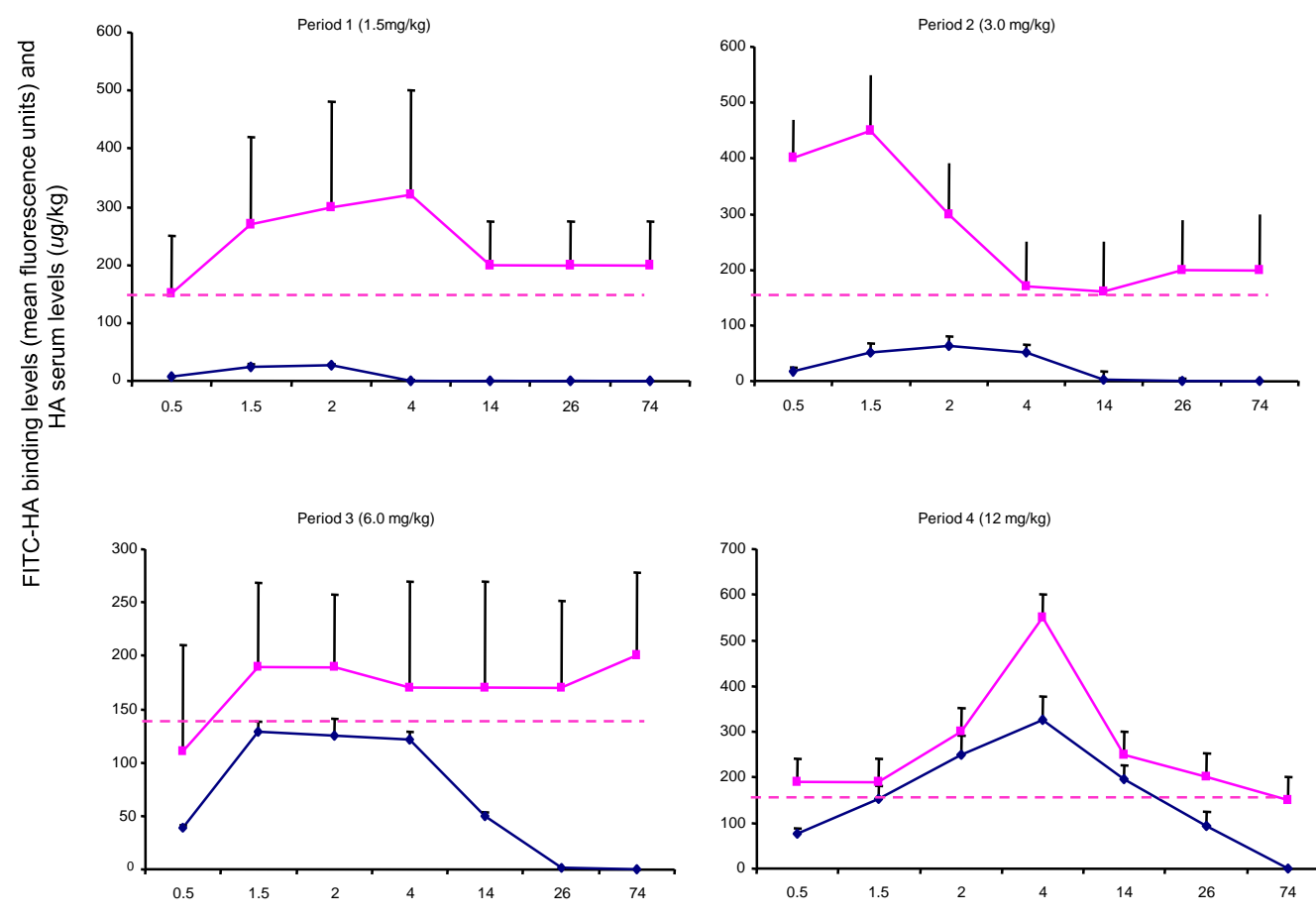

Time after HA infusion (Hrs)
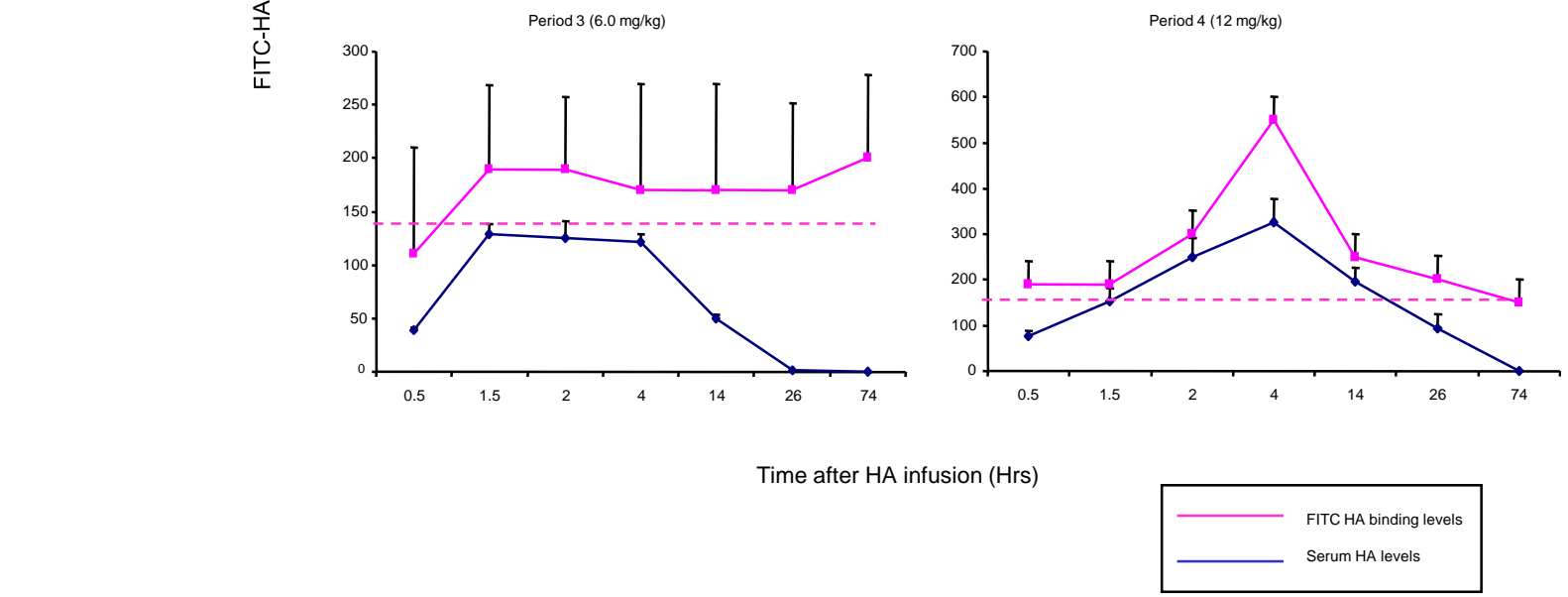

Fig. (4). Pharmacodynamics of FITC-HA binding to CD14+ PBMC and serum HA levels. The pharmacodynamics of FITC-HA binding to CD14+ PBMC vs. serum HA levels were different for each dosing period but generally FITC-HA binding to monocytes initially increased with rising serum HA levels during all infusion periods $(0-2 \mathrm{hr}$ time points for each dosing period). FITC-HA binding and serum HA levels declined to baseline (dotted line represents baseline FITC-HA binding and baseline values have been subtracted from serum HA levels, see Subjects, Materials and Methods for details) in a roughly coordinated fashion during the first two dosing periods but FITC-HA binding remained higher than baseline in period 3 when serum HA levels had dropped. By the $4^{\text {th }}$ dosing period, FITC-HA binding to CD14+ PBMC and serum HA levels rose and fell in unison.

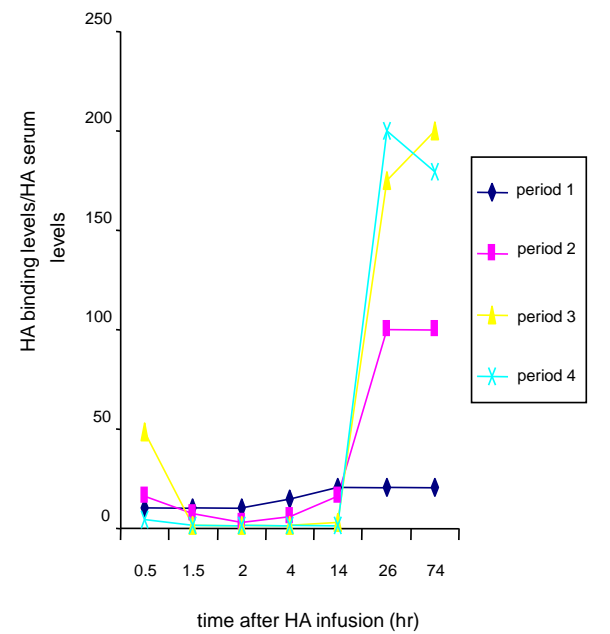

Fig. (5). FITC-HA binding capacity of CD14+ PBMC. The ratio of FITC-HA binding/serum HA level was calculated to obtain a standardized HA binding capacity for each dosing period. Using this measure, the FITC-HA binding capacity was not altered during the duration of sampling for the first period. Binding capacity also did not increase during the first $14 \mathrm{hr}$ of subsequent dosing periods but did increase between 14-74 $\mathrm{hr}$ of the second dosing period and further increased to maximum levels between 14-74 hrs in the $3^{\text {rd }}$ and $4^{\text {th }}$ periods. a number of studies report that HA/drug mixtures increase targeted-delivery of drugs to tumors and enhance the drug's therapeutic efficacy $[21,51]$, and HA by itself may have beneficial biomodifying effects $[47,52,53]$. Specific sizes of $\mathrm{HA}$ are reported to induce tumor apoptosis and reduce tumor metastasis in vivo $[2,7]$ These positive experimental studies and increased interest in using HA as an imaging agent predict a dramatic increase in the extent and type of clinical use of HA in the near future. Our present study provides a foundation for characterizing the metabolism of chronic, pharmacological doses of HA administered i.v. in humans.

The pharmacological doses of HA infused into healthy subjects during this study were well tolerated. No clinically serious adverse events were observed that could be related to these infusions. This is consistent with the previously established safety record for HA and with a minimal distribution of administered HA predicted from the small apparent $\mathrm{V}_{\mathrm{d}}$. As well, there was no evidence for the generation of HA fragments (which activate the pro-inflammatory function of HA $[4,12]$ and might be associated with adverse reactions) over this study period. Indeed, the smallest HA fraction $(<37.7 \mathrm{kDa})$ decreased with time after HA infusion. The apparent lack of fragmentation of serum HA is similar to a report that also noted no significant changes over time in the molecular weight of exogenous HA injected into joints [10, 
B.
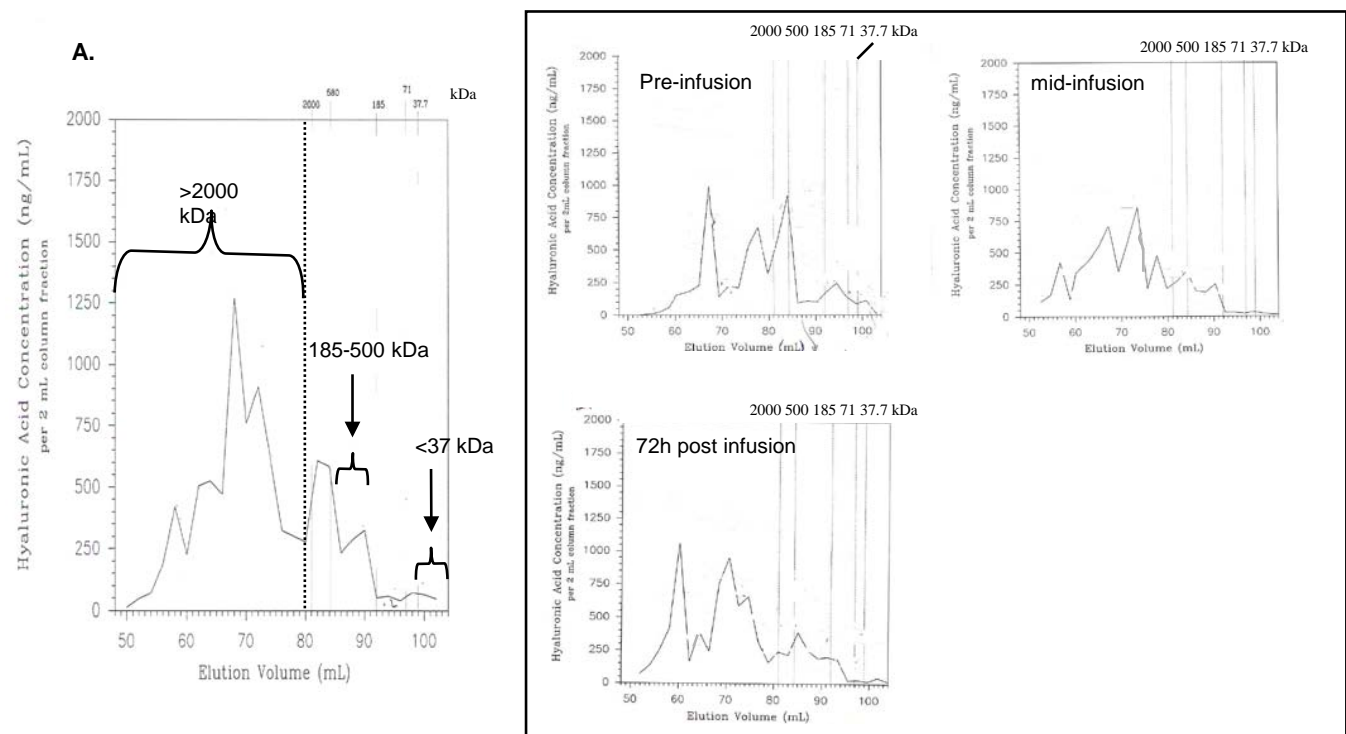

$$
\text { c. }
$$
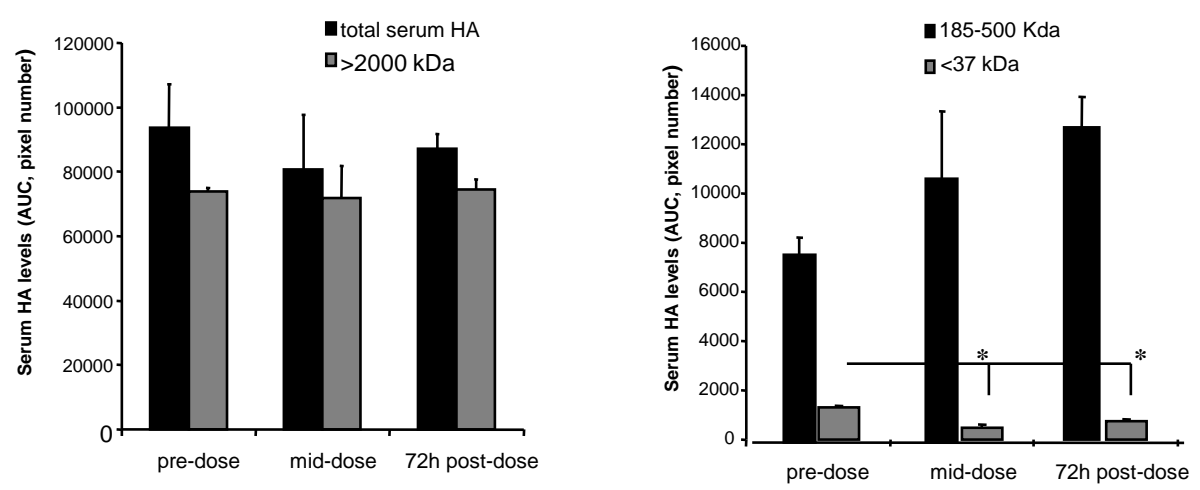

Fig. (6). Molecular weight analysis of serum HA from period $4(12 \mathrm{mg} / \mathrm{kg})$.

A. A typical molecular weight profile of serum HA, quantified by a modified anthrone assay following separation with gel filtration. High molecular weight HA (<2000 kDa), 185-500 kDa HA, which corresponded to the infused exogenous HA, and small molecular weight HA $(<37 \mathrm{kDa})$ were quantified using image analysis to obtain pixel number in the area under the curve (AUC) as indicated in this sample profile. B. The molecular weight profiles HA sampled from one volunteer is shown $2 \mathrm{~h}$ prior to infusion of HA $\left(4^{\text {th }}\right.$ period, $\left.12 \mathrm{mg} / \mathrm{kg}\right)$, mid-infusion (at $1.5 \mathrm{~h}$ ) and $72 \mathrm{~h}$ post-infusion. Equal amounts of CPC-precipitated HA were loaded onto the columns for each time period. C. The molecular weight profiles of 4 volunteers were obtained as in (B) and AUC were calculated. Significant differences between the dosing times were not detected for the high molecular weight or the $185-500 \mathrm{kDa}$ fractions. However, the amount of small molecular weight $\mathrm{HA}(<37 \mathrm{kDa})$ present in serum is significantly reduced following infusion of exogenous HA ( $<<0.01$, Student's $t$-test). Values represent the mean and S.E.M. $n=6$.

54]. In addition to possible fragment generation, adverse reactions attributed to $\mathrm{HA}$ have also been linked to the presence of either DNA or protein contamination [34]. However, the HA preparations used in this study did not contain detectable protein or DNA, consistent with the desirable safety profile noted in our study. Our safety profile in healthy volunteers is thus similar to that of HA given as i.v. bolus doses in either healthy volunteers or patients with arthritis or liver cirrhosis [54], or to cancer patients given multiple, high doses of HA [55]. Cancer patients with Wilm's tumors or mesotheliomas have high endogenous circulating levels of HA (approximating 6-12 $\mathrm{mg} / \mathrm{kg}$ ) that disappear with removal of their tumors [56]. Adverse effects directly associated with these high HA levels are mild but include moderate inhibition of platelet aggregation and selective suppression of the immunogenicity of some serum protein. We similarly found that even after repeated exposure to high levels of HA, platelet aggregation was within normal limits during the washout periods, and thus HA did not have a sustained effect on aggregation.

Our results extend previously reported effects of serum HA on vascular physiology to include an effect of high serum HA levels on the ability of PBMC, in particular circulating monocytes, to bind HA. Enhanced binding, which can result from a variety of factors including receptor expression, activation, display and kinetics of recycling to the cell surface did not adversely affect vascular functions that were tested in the present study. However, HA binding to 
immune cells through such receptors as CD44 and RHAMM affect trafficking and survival of leukocytes $[4,57,58]$, and promote such immune cell functions as pro-inflammatory cytokine production [4] and differentiation of blast and other cells [12]. Further studies are required to assess whether or not these immune functions are affected by high serum HA.

Interestingly, $\mathrm{V}_{\mathrm{d}}$ and $\mathrm{V}_{\max }$ were similar across HA doses but the $K_{\text {syn }}$ and $K_{m}$ values varied. $K_{m}$ values were lowest at the lowest HA dose $(1.5 \mathrm{mg} / \mathrm{kg})$ and highest at the higher HA dose $(12 \mathrm{mg} / \mathrm{kg})$ administered. The $\mathrm{K}_{\mathrm{m}}$ is related to ligand-receptor affinity and HA metabolism from serum is a receptor-mediated process [14]. Therefore, one interpretation of these results is that high HA levels (e.g., $12 \mathrm{mg} / \mathrm{kg}$ ) reduces the efficiency of HA-mediated uptake in the tissue compartments such as liver endothelium and kidney that are largely responsible for clearing serum HA. However, it is likely that the mechanism(s) underlying alteration of $\mathrm{K}_{\mathrm{m}}$ are more complex. For example, monocytes exhibit increased rather than decreased FITC-HA binding when exposed to high serum HA levels, although they express different HA receptors than do liver endothelial cells and these may be differentially regulated by serum HA [14]. HA can adsorb onto vascular endothelium via non-receptor-mediated mechanisms. For example, growth of polyelectrolyte multilayers occurs when a charged surface is dipped into a polyanion solution such as HA [59]. In addition, HA can be sequestered in multiple compartments including the vascular tree, lymphatics and such organ tissues as the liver and kidneys. Although the $V_{d}$ appears to be unchanged with dose access to sub-compartments that are essential for HA elimination may be affected by serum HA levels, a restriction that could affect $\mathrm{K}_{\mathrm{m}}$. This possibility is suggested by the change in $\mathrm{k}_{\mathrm{syn}}$ with dose escalation. Clearly, further studies are required to establish the pharmacodynamic mechanisms for the altered $\mathrm{K}_{\mathrm{m}} v s$. blood cell HA receptor binding. Regardless, these results suggest that $\mathrm{HA}$ has a saturable metabolism and, as a consequence, the half-life of elimination will dynamically change with concentration, as predicted by the model presented in Fig. (1).

In summary, the present study describes dose-dependent (Michaelis-Menten) elimination kinetics of escalating doses of HA in healthy volunteers. Our study provides a pharmacokinetic analysis that is favorable for further development of HA polymers modified with metals (such as gadolinium) as imaging agents [25]. Regardless of the mechanisms by which HA is eliminated, this study demonstrates that healthy human subjects tolerate escalating injected doses of HA and sustained serum HA levels with no treatment-related side effects, providing a favorable safety profile for use of HA in drug delivery/enhancement, white cell trafficking, or other uses. Processes that increase HA binding to cells including disease states or as noted in the present study, exposure to $\mathrm{HA}$, is associated with altered elimination kinetics and it will be interesting to determine whether or not detection of changes in elimination kinetics can be used to monitor HAmediated disease processes.

\section{ACKNOWLEDGEMENT}

The technical assistance of Ms. J. Ma is gratefully acknowledged. All authors have stated that they have no conflicts of interest.

\section{FUNDING}

This study was originally supported by Hyal Pharma Corp (Mississauga, Ontario, Canada) and SkyePharme Inc. (London, UK). Data analysis and preparation were funded by BioMS Medical (Edmonton, Alberta, Canada). Additional funding was provided by the Breast Cancer Research Foundation (ET), CIHR (ET, MOP-57694; JK, MOP-62836), CIHR fellowship (SH, UST-63811), NIH (R.S. grants HL62472, HL073896); NCI/NIH (M.V. PDF F32 CA132491).

\section{ABBREVIATIONS}

$$
\begin{aligned}
& \text { ADC }=\text { apparent diffusion coefficient } \\
& \text { AUC = area under the curve } \\
& \mathrm{B}-\mathrm{HCG}=\text { Beta-human chorionic gonadotropin } \\
& \text { BUN }=\text { Blood urea nitrogen } \\
& \mathrm{C}_{\max }=\text { maximum plasma concentration } \\
& \text { CD4+ = Thymocyte/T subset } \\
& \text { CD8+ = Thymocyte/T subset } \\
& \text { CD14+ = Monocyte/macrophage } \\
& \mathrm{CD} 19+=\mathrm{B} \text { cell activation } \\
& \text { CD44 = Hyaluronan/homing receptor } \\
& \text { CNS }=\text { central nervous system } \\
& \mathrm{Da} \quad=\text { Daltons } \\
& \mathrm{kDa}=\text { kilodaltons } \\
& \text { FACS }=\text { fluorescence activated cell sorting } \\
& \text { FITC }=\text { fluorescein } \\
& \text { HA }=\text { Hyaluronan } \\
& \text { HARE }=\text { Hyaluronan receptors of Endothelium } \\
& \text { HAS1-3 = Hyaluronan synthases 1-3 } \\
& \text { HIV }=\text { Human immunodeficiency virus } \\
& \text { HPLC }=\text { High Pressure Liquid Chromatography } \\
& \text { HYAL1-5 = Hyaluronidases 1-5 } \\
& \text { I.V. }=\text { intravenous } \\
& \mathrm{K}_{\mathrm{m}} \quad=\text { Michaelis-Menten constant } \\
& \mathrm{K}_{\text {syn }} \quad=\text { synthesis constant } \\
& \mathrm{LDH}=\text { Lactate dehydrogenase } \\
& \text { LOD = limit of detection } \\
& \text { LOQ = limit of quantification } \\
& \text { LYVE-1 = lymph vessel endothelial-1 } \\
& \mathrm{MAb}=\text { monoclonal antibody } \\
& \text { MRI }=\text { magnetic resonance imaging } \\
& \text { MW }=\text { molecular weight } \\
& \text { PBMC = peripheral blood mononuclear cells } \\
& \text { PBS }=\text { phosphate buffered saline } \\
& \text { PD }=\text { Pharmacodynamics }
\end{aligned}
$$




$$
\begin{array}{ll}
\text { PE } & =\text { Phycoerythrin } \\
\text { PK } & =\text { Pharmacokinetics } \\
\text { PT/PTT } & =\text { Prothrombin time/activated prothrombin time } \\
\text { RHAMM } & =\text { receptor for hyaluronan mediated motility } \\
\text { SGOT } & =\text { serum glutamic-oxaloacetic transaminase } \\
\text { SGPT } & =\text { serum glutamic-pyruvic transaminase } \\
\text { UV } & =\text { ultraviolet } \\
\text { Vd } & =\text { volume of distribution } \\
V_{m} & =\text { elimination coefficient } \\
V_{\max } & =\text { maximum elimination rate }
\end{array}
$$

\section{REFERENCES}

[1] Tammi, M.I.; Day, A.J.; Turley, E.A. Hyaluronan and homeostasis: a balancing act. J. Biol. Chem., 2002, 277(7), 4581-4584.

[2] Toole, B.P. Hyaluronan: from extracellular glue to pericellular cue. Nat. Rev. Cancer, 2004, 4(7), 528-39.

[3] Laurent, T.C.; Fraser, J.R. Hyaluronan. FASEB J., 1992, 6(7), 2397-2404.

[4] Jiang, D.; Liang, J.; Noble, P.W. Hyaluronan in tissue injury and repair. Annu. Rev. Cell Dev. Biol., 2007, 23, 435-61.

[5] Itano, N. Simple primary structure, complex turnover regulation and multiple roles of hyaluronan. J. Biochem., 2008, 144(2), 131137.

[6] Fraser, J.R.; Laurent, T.C. Turnover and metabolism of hyaluronan. Ciba Found Symp., 1989, 143, 41-53; discussion 53-9, 281-285.

[7] Toole, B.P.; Slomiany, M.G. Hyaluronan: a constitutive regulator of chemoresistance and malignancy in cancer cells. Semin. Cancer Biol., 2008, 18(4), 244-250.

[8] Friedman, P.M.; Mafong, E.A.; Kauvar, A.N.; Geronemus, R.G. Safety data of injectable nonanimal stabilized hyaluronic acid gel for soft tissue augmentation. Dermatol. Surg., 2002, 28(6), 491494.

[9] Geier, K.A.; Keeperman, J.B.; Sproul, R.C.; Roth, K.; Reynolds, H.M. Viscosupplementation: a new treatment option for osteoarthritis. Orthop. Nurs., 2002, 21(5), 25-32.

[10] Itokazu, M.; Matsunaga, T. Clinical evaluation of high-molecularweight sodium hyaluronate for the treatment of patients with periarthritis of the shoulder. Clin. Ther., 1995, 17(5), 946-955.

[11] Turley, E.A.; Noble, P.W.; Bourguignon, L.Y. Signaling properties of hyaluronan receptors. J. Biol. Chem., 2002, 277(7), 4589-4592.

[12] Slevin, M.; Kumar, S.; Gaffney, J. Angiogenic oligosaccharides of hyaluronan induce multiple signaling pathways affecting vascular endothelial cell mitogenic and wound healing responses. J. Biol. Chem., 2002, 277(43), 41046-59.

[13] Jackson, D.G. The lymphatics revisited: new perspectives from the hyaluronan receptor LYVE-1. Trends Cardiovasc. Med., 2003, 13(1), 1-7.

[14] Weigel, P.H.; Yik, J.H. Glycans as endocytosis signals: the cases of the asialoglycoprotein and hyaluronan/chondroitin sulfate receptors. Biochim. Biophys. Acta, 2002, 1572(2-3), 341-363.

[15] Stern, R. Hyaluronidases in cancer biology. Semin. Cancer Biol., 2008, 18(4), 275-280.

[16] Lokeshwar, V.B.; Selzer, M.G. Hyalurondiase: both a tumor promoter and suppressor. Semin. Cancer Biol., 2008, 18(4), 281-7.

[17] Abate, M.; Pelotti, P.; De Amicis, D.; Di Iorio, A.; Galletti, S.; Salini, V. Viscosupplementation with hyaluronic acid in hip osteoarthritis (a review). Ups J. Med. Sci., 2008, 113(3), 261-277.

[18] Cohen, J.L. Understanding, avoiding, and managing dermal filler complications. Dermatol. Surg., 2008, 34(Suppl 1), S92-9.

[19] Hunter, D.J.; Hellio Le Graverand-Gastineau, M.P. How close are we to having structure-modifying drugs available? Med. Clin. North Am., 2009, 93(1), 223-234.

[20] Maria, B.L.; Gupta, N.; Gilg, A.G.; Abdel-Wahab, M.; Leonard, A.P.; Slomiany, M.; Wheeler, W.G.; Tolliver, L.B.; Babcock, M.A.; Lucas, J.T. Jr.; Toole, B.P. Targeting hyaluronan interactions in spinal cord astrocytomas and diffuse pontine gliomas. J. Child. Neurol., 2008, 23(10), 1214-1220.
[21] Eliaz, R.E.; Szoka, F.C. Jr. Liposome-encapsulated doxorubicin targeted to CD44: a strategy to kill CD44-overexpressing tumor cells. Cancer Res., 2001, 61(6), 2592-2601.

[22] Ruponen, M.; Ronkko, S.; Honkakoski, P.; Pelkonen, J.; Tammi, M.; Urtti, A. Extracellular glycosaminoglycans modify cellular trafficking of lipoplexes and polyplexes. J. Biol. Chem., 2001, 276(36), 33875-33880.

[23] Luo, Y.; Ziebell, M.R.; Prestwich, G.D. A hyaluronic acid-taxol antitumor bioconjugate targeted to cancer cells. Biomacromolecules, 2000, 1(2), 208-18.

[24] Vignal, P.; Meslet, M.R.; Romeo, J.M.; Feuilhade, F. Sonographic morphology of infiltrating breast carcinoma: relationship with the shape of the hyaluronan extracellular matrix. J. Ultrasound Med., 2002, 21(5), 532-538.

[25] Gouin, S.; Winnik, F.M. Quantitative assays of the amount of diethylenetriaminepentaacetic acid conjugated to water-soluble polymers using isothermal titration calorimetry and colorimetry. Bioconjug. Chem., 2001, 12(3), 372-377.

[26] Lindqvist, U. Is serum hyaluronan a helpful tool in the management of patients with liver diseases? J. Intern. Med., 1997, 242(1), 6771.

[27] Lindqvist, U.; Groth, T.; Lebel, L. Evaluation of various models of hyaluronan kinetics for assessment of liver function. Scand. J. Clin. Lab. Invest., 1997, 57(1), 49-58.

[28] Lebel, L.; Gabrielsson, J.; Laurent, T.C.; Gerdin, B. Kinetics of circulating hyaluronan in humans. 4. Eur. J. Clin. Invest., 1994, 24(9), 621-626.

[29] Shah, B.; Sucher, K.; Hollenbeck. C.B. Comparison of ideal body weight equations and published. Nutr. Clin. Pract., 2006, 21(3), 312-319.

[30] Pledger, G. Proof of efficacy trials: choosing the dose. Epilepsy Res., 2001, 45(1-3), 23-8.

[31] Suri, A.; Estes, K.S.; Geisslinger, G.; Derendorf, H. Pharmacokinetic-pharmacodynamic relationships for analgesics. Int. J. Clin. Pharmacol. Ther., 1999, 35(8), 307-323.

[32] Helsinki, D.O. Ethical Principles for Medical Research Involving Human Subjects; $41^{\text {st }}$ WMA General Assembly: Hong Kong, 1989.

[33] Masellis-Smith, A.; Belch, A.R.; Mant, M.J.; Turley, E.A.; Pilarski L.M. Hyaluronan-dependent motility of B cells and leukemic plasma cells in blood, but not of bone marrow plasma cells, in multiple myeloma: alternate use of receptor for hyaluronan-mediated motility (RHAMM) and CD44. Blood, 1996, 87(5), 1891-1899.

[34] Filion, M.C.; Phillips, N.C. Pro-inflammatory activity of contaminating DNA in hyaluronic acid preparations. J. Pharm. Pharmacol., 2001, 53(4), 555-561.

[35] Hjerpe, A.; Antonopoulos, C.A.; Engfeldt, B.; Wilstrom, B. Analysis of dentine glycosaminoglycans using high-performance liquid chromatography. Calcif Tissue Int., 1983, 35(4-5), 496-501.

[36] Somani, B.L.; Khanade, J.; Sinha, R. A modified anthrone-sulfuric acid method for the determination of fructose in the presence of certain proteins. Anal. Biochem., 1987, 167(2), 327-330.

[37] Thompson, G.A.; Shumaker, R.C. MLTIDOSE: a multiple-dose simulation program for linear systems characterized by exponential functions. Drug Metab. Rev., 1989, 21(3), 463-469.

[38] Lindqvist, U.; Groth, T.; Loof, L.; Hellsing, K. A hyaluronanloading test applied to patients with liver and joint diseases. Clin. Chim. Acta, 1992, 210(1-2), 119-32.

[39] Maxwell, C.A.; McCarthy, J.; Turley, E. Cell-surface and mitoticspindle RHAMM: moonlighting or dual oncogenic functions? $J$. Cell Sci., 2008, 121 (Pt 7), 925-932.

[40] Salisbury, B.G.; Wagner, W.D. Isolation and preliminary characterization of proteoglycans dissociatively extracted from human aorta. J. Biol. Chem., 1981, 256(15), 8050-8057.

[41] Schmidt, A.; von Teutul, A.; Buddecke, E. Characterization of proteoglycans synthesized by cultured arterial smooth muscle cells of the rat. Hoppe Seylers Z Physiol. Chem., 1984, 365(4), 445-456.

[42] Rogers, H.J. Very high molecular weight mucopolysaccharides and mucopolysaccharide-protein complexes--how far can we extrapolate? Fed. Proc., 1966, 25(3),1035-1036.

[43] Balazs, E.A.; Bland, P.A.; Denlinger, J.L.; Goldman, A.I.; Larsen, N.E.; Leschiner, E.A.; Leschiner, A.; Morales, B. Matrix engineering. Blood Coagul. Fibrinolysis, 1991, 2(1), 173-178.

[44] Rosier, R.N.; O'Keefe, R.J. Hyaluronic acid therapy. Instr. Course Lect., 2000, 49, 495-502. 
[45] Jarvis, B.; Figgitt, R.J. Topical 3\% diclofenac in $2.5 \%$ hyaluronic acid gel: a review of its use in patients with actinic keratoses. Am. J. Clin. Dermatol., 2003, 4(3), 203-213.

[46] Espallargues, M.; Pons, J.M. Efficacy and safety of viscosupplementation with Hylan G-F 20 for the treatment of knee osteoarthritis: a systematic review. Int. J. Technol. Assess Health Care, 2003, 19(1), 41-56.

[47] Balazs, E.A. Analgesic effect of elastoviscous hyaluronan solutions and the treatment of arthritic pain. Cells Tissues Organs, 2003, 174(1-2), 49-62.

[48] Lane, S.S.; Lindstrom, R.L. Viscoelastic agents: formulation, clinical applications, and complications. Semin. Ophthalmol., 1992, 7(4), 253-260.

[49] Liesegang, T.J. Viscoelastic substances in ophthalmology. Surv. Ophthalmol., 1990, 34(4), 268-293.

[50] Pavesio, A.; Renier, D.; Cassinelli, C.; Morra, M. Anti-adhesive surfaces through hyaluronan coatings. Med. Device Technol., 1997, 8(7), 24-27.

[51] Cera, C.; Plumbo, M.; Stefanelli, S.; Rassu, M.; Palu, G. Watersoluble polysaccharide-anthracycline conjugates: biological activity. Anticancer Drug Des., 1992, 7(2), 143-151.

[52] Thierry, B.; Winnik, F.M.; Merhi, Y.; Silver, J.; Tabrizian, M. Radionuclides-hyaluronan-conjugate thromboresistant coatings to prevent in-stent restenosis. Biomaterials, 2004, 25(17), 3895-3905.

[53] Heublein, B.; Evagorou, E.G.; Rohde, R.; Ohse, S.; Meliss, R.R.; Barlach, S.; Haverich A. Polymerized degradable hyaluronan--a platform for stent coating with inherent inhibitory effects on neoin- timal formation in a porcine coronary model. Int. J. Artif. Org., 2002, 25(12), 1166-1173.

[54] Lindqvist, U.; Tolmachev, V.; Kairemo, K.; Astrom, G.; Jonsson, E.; Lundqvist, H. Elimination of stabilised hyaluronan from the knee joint in healthy men. Clin. Pharmacokinet, 2002, 41(8), 603 613.

[55] Matrosova, V.Y.; Orlovskaya, I.A.; Serobyan, N.; Khaldoyanidi, S.K. Hyaluronic acid facilitates the recovery of hematopoiesis following 5-fluorouracil administration. Stem Cells, 2004, 22(4), 544555.

[56] Lin, R.Y.; Argenta, P.A.; Sullivan, K.M.; Stern, R.; Adzick N.S. Urinary hyaluronic acid is a Wilms' tumor marker. J. Pediatr. Surg., 1995, 30(2), 304-308.

[57] Pilarski, L.M.; Pruski, E.; Wizniak, J.; Paine, D.; Seeberger, K.; Mant, M.J.; Brown, C.B.; Belch, A.R. Potential role for hyaluronan and the hyaluronan receptor RHAMM in mobilization and trafficking of hematopoietic progenitor cells. Blood, 1999, 93(9), 29182927.

[58] McDonald, B.; McAvoy, E.F.; Lam, F.; Gill, V.; de la Motte, C.; Savani, R.C.; Kubes, P. Interaction of CD44 and hyaluronan is the dominant mechanism for neutrophil sequestration in inflamed liver sinusoids. J. Exp. Med., 2008, 205(4), 915-927.

[59] Thierry, B.; Winnik, F.M.; Merhi, Y.; Tabrizian, M. Nanocoatings onto arteries via layer-by-layer deposition: toward the in vivo repair of damaged blood vessels. J. Am. Chem. Soc., 2003 125(25), 74947495 .

(C) Hamilton et al.; Licensee Bentham Open.

This is an open access article licensed under the terms of the Creative Commons Attribution Non-Commercial License (http://creativecommons.org/licenses/by-nc/3.0/) which permits unrestricted, non-commercial use, distribution and reproduction in any medium, provided the work is properly cited. 